\title{
'The Antifascist Kick': A Signifying Cultural Practice in the History of Transnational Antifascism?
}

\author{
Victor Lundberg \\ Department of Global Political Studies, Malmö University, Malmö, Sweden \\ Victor.Lundberg@mau.se
}

\begin{abstract}
This article is based on an empirical study of 'the antifascist kick' as a formative cultural practice in the history of transnational antifascism. It scopes from the 193os and the era of opposition to classic fascism, through to the twenty-first century where antifascism encounters political processes of globalization, fragmentation, neoliberalism, and neofascism. The article discusses the 'antifascist kick' in different historical contexts, from 1930s Sweden to Germany and the United States today. The article reveals that 'the antifascist kick' works in various cultural directions: as a political conception of those who are only worth contempt, as a symbolic representation of the antifascist struggle, and as a practical instruction for how to treat fascists in the streets.
\end{abstract}

\section{Keywords}

Germany - Sweden - United States of America - antifascism - transnationalism - ANTIFA

\section{A Historic Kick}

In 1934, many Europeans, from all social classes, were impressed and fascinated by the development of fascism, especially in Germany. There, National Socialism under the leadership of Adolf Hitler, seemed to turn recession, unemployment, misery, and social unrest into stability, progress, welfare, and growth. As Mark Mazower stresses in Dark Continent. Europe's Twentieth Century, fascism was considered a new and promising political force, constituting a starting point for a new and modern European society, freed from social conflicts

(C) VICTOR LUNDBERG, 2020 | DOI:10.1163/22116257-09010007

This is an open access article distributed under the terms of the prevailing CC-BY-NC license at the time of publication. 
and political and economic disorder. ${ }^{1}$ Fascism was seen by many as 'a transnational political alternative to democracy'. ${ }^{2}$ Others, particularly left-wing and liberal politicians, publicists and intellectuals, but also many 'ordinary people' in the working and middle classes, were worried and scared. Their desire for a more equal society - economically, politically, socially and culturally - was challenged and in several societies on the European continent successively pulverized. The rise of National Socialism in Germany and its establishment of the Third Reich, as well as Mussolini's formation of the Italian Fascist state and the fascistic power aspirations of the Falangists in Spain, was based on a pervasive national transformation of society. In the 1930s, dictatorships matured and soon became more and more blood-stained. Many 'unwanted' social categories in Europe faced disdain and violence, not least in the human catastrophes of the Second World War. ${ }^{3}$

To confront this fateful fascistization, European antifascism mobilized, opposed and resisted in many various ways. In Italy, anarchists had developed a radical and militant antifascist tradition with the emergence of fascism as a mass movement, a violent way to fight fascism that would deeply influence and inspire transnational European antifascism. ${ }^{4}$ The antagonism between fascists and communists and/or anarchists thus became bloody and deadly in many parts of Europe during the interwar period. In Sweden, on the other hand, the early antifascist organization was predominantly peaceful. There, the Social Democratic Youth Organisation for instance channelled

$1 \quad$ Mark Mazower, Dark Continent: Europe's Twentieth Century (London: Penguin Books, 1999). See also: Roger Griffin, Modernism and Fascism: The Sense of a Beginning Under Mussolini and Hitler (Houndmills, Basingstoke, Hampshire: Palgrave MacMillan, 2007).

2 Arnd Bauerkämper and Grzegorz Rossolinski-Liebe, 'Introduction: Fascism Without Borders: Transnational Connections and Cooperation between Movements and Regimes in Europe, 1918-1945,' in Fascism Without Borders: Transnational Connections and Cooperation between Movements and Regimes in Europe from 1918-1945, ed. Arnd Bauerkämper and Grzegorz Rossolinski-Liebe (New York: Berghahn Books, 2017), 16.

3 Shelley Baranowski, Armin Nolzen and Claus-Christian W. Szejnmann, ed., A Companion to Nazi Germany (Hoboken: John Wiley \& Sons, 2018); Eric A. Johnson and Karl-Heinz Reuband, What We Knew: Terror, Mass Murder and Everyday Life in Nazi Germany: An Oral History (Cambridge: Basic Books, 2006); George L. Mosse, The Nationalization of the Masses: Political Symbolism \& Mass Movements in Germany From the Napoleonic Wars Through the Third Reich (New York: Howard Fertig, 1975).

4 Nigel Copsey, 'Radical Diasporic anti-Fascism in the 1920s: Italian Anarchists in the EnglishSpeaking World,' in Anti-Fascism in a Global Perspective: Transnational Networks, Exile Communities, and Radical Internationalism, ed. Kasper Braskén, Nigel Copsey and David Featherstone (Abingdon: Routledge, 2020). 
their antifascist beliefs through fictive short stories in their membership paper where the reader was figuratively instructed to give fascists 'a fierce punch and a well-targeted kick'when they showed up. ${ }^{5}$

From the beginning, the antifascist struggle in Europe was characterized by multifaceted complexity and heterogeneity, diverse ideological standpoints, different methods, rival traditions and fruitful transnational inspirations and co-operations. In this article, I investigate one partial aspect of the antifascist struggle from a diachronic and transnational historical perspective. More specifically, the aim is to analyse 'the antifascist kick' as a manifold and (figuratively) violent sociocultural action, advocated by antifascist groups on the political left-wing, in four different historical contexts that extends from 1930 S Sweden to recent events in Germany and the US. The analysis is directed towards different representations, legitimations, and discursive meanings of 'the antifascist kick' and strives to answer the following question: In what ways could 'the antifascist kick' be understood as a signifying sociocultural practice?

My thesis here is that this kind of (figurative) antifascist violence, 'the antifascist kick', is symbolically maintained as a formative sociocultural signifier in the heterogenous history of transnational antifascism; generating ways to, both literately and figuratively, confront fascism, create unity, stimulate and sustain an antifascist fighting spirit. ${ }^{6}$ Methodologically the analysis is based on Stuart Hall's analytical framework for critical deconstruction of discursive representations and phenomena as socioculturally significant and meaningful in terms of social categories, power relations, and 'natural and obvious facts' in society. ${ }^{7}$

The four different historical contexts that are analysed in the article range from Sweden during 1934, via Michigan (U.S.) in 1998, to 2017 in Germany and the United States. This sample is made with the intention of grasping a small but eloquent fragment of the complexity of antifascist sociocultural expressions and world views in both time and space. Due to this, the analytical aim is not quantitative or representational but instead qualitative.

$5 \quad$ Frihet, 15 April 1934, 11.

6 For a discussion and definition of the analytical concept 'signifier', see Stuart Hall, 'The Work of Representation,' in Representation: Cultural representations and signifying practices, ed. Stuart Hall (London: Sage, 1997), 31.

7 Stuart Hall, 'The Spectacle of the Other,'in Representation: Cultural representations and signifying practices, ed. Stuart Hall (London: Sage, 1997). See also Theo van Leeuwen, 'Legitimation in discourse and communication,' Discourse \& Communication 1 (2007): 91-112. 


\section{Antifascism: an Ambiguous Transnational Phenomenon}

Across Europe, violent confrontations between fascists and antifascists became more and more common during the 1930s. Beside organized rallies, demonstrations, riots, and sabotage, in protest against growing fascism, fascists were also sometimes violently confronted, assaulted and assassinated by enraged antifascists. Thus, it is important to keep in mind that fascism in many aspects and contexts is simply to be considered as radical anti-communism. ${ }^{8}$ This antifascist struggle was in some countries a form of civil war against armed paramilitaries, while in other countries it was more tense and supressed, regulated by state authorities or organized through the pervasive power structures of established political parties or trade unions.

A crucial internal consideration within the multifaceted field of antifascism in history deals with sensitive questions about organization forms and collaborators. During the 1930s, tensions and hostilities among different left-wing parties and organisations were brought to a head when fascism came under fire. According to Tim Kirk and Anthony McElligott: 'national resistance movements rarely existed in pure form. Resistance came from a variety of disparate, often mutually hostile groups, whose cohesion in the cause of a common patriotic aim was often nominal at best. Indeed, even where a notional ideological unity appeared to exist, the reality was often more complex. ${ }^{9}$

Antifascism encompassed various beliefs and ways to defend what were/are seen as fundamental rights from the forces and groups that sought to reverse them. ${ }^{10}$ In this sense, antifascism needs to be studied in its changing historical contexts, analysing the malleability and fluidity of antifascists cultures. The republican antifascist violence during the Spanish Civil War was of another nature than the anarchist violence used by ANTIFA activists against police, authorities or far-right demonstrators in late twentieth and early twenty-first century. Thus, understanding antifascism also needs an appropriate and nuanced understanding of fascism; how it appears, how it behaves, and where it is hiding.

8 Victor Lundberg, 'A Fascist Baby Hawk in Nuremberg: Five Swedish Fascists' Road Trip to the Fourth Nazi Party Congress - and the Socialization of a Nazi Mind,' Journal for the Study of Radicalism 14 (2020): 2; Walter Laqueur, ed., Fascism: A Readers Guide: Analyses, Interpretations, Bibliography (Berkeley and Los Angeles: University of California Press, 1976); Martin Durham and Margaret Power, ed., New Perspectives on the Transnational Right (Basingstoke: Palgrave MacMillan, 2010).

9 Tim Kirk and Anthony McEllligott, ed., Opposing Fascism: Community, Authority, and Resistance in Europe (Cambridge: Cambridge University Press, 1999), 7.

10 Ibid., 6. 
Consequently, as international research points out, antifascism as a historical phenomenon has to be understood and approached as a wide, tense, and multifaceted, political forcefield. ${ }^{11}$ Here, a wide range of political actors and actions can be found, from peaceful and concerned liberals, opposing fascism by writing angry articles and publishing enlightening news, to violent and ferocious street activists, fighting fascism and fascists in a very concrete way, sometimes in ambivalence between on one hand rational political and ideological standpoints and on the other hand emotional actions and terrifying experiences.

Eve Rosenhaft's study of communist resistance in late Weimar Germany clarifies this ambivalence. According to her, the resistance of communist antifascists had to be 'a self-defence movement vigorous enough to discourage attack and maintain the integrity of the Communist movement, and so organized as to fulfil certain fundamental agitational functions, but not so aggressive or ideologically insensitive as to prejudice the chances for a broad front of the "labouring masses".'12 The fascist workers had to be attracted over to the other side, and with that intention, violence may not have been the most appropriate method. The balance between as much violence as required and too much violence was, in other words, delicate. ${ }^{13}$

Due to the fact that violence is an ideological and socio-cultural cornerstone in fascism, ${ }^{14}$ antifascism and antifascists inevitably have to deal with the question of the use of violence, naturally as self-defence but also to safeguard societal property and democratic values and structures in society. Internally, the question of 'fighting fascism with its own weapons' became

11 See for example the vital anthologies: Giovanni Cappocia, Defending Democracy: Reactions to Extremism in Interwar Europe (Baltimore: John Hopkins University Press, 2005); Nigel Copsey and Andrzej Olechnowicz, ed., Varieties of Anti-Fascism: Britain and the Inter-War Period (Basingstoke: Palgrave MacMillan, 2010); Hugo García, Mercedes Yusta, Xavier Tabet and Christina Climaco, ed., Rethinking Antifascism: History, Memory and Politics, 1922 to the Present (New York: Berghahn Books, 2016).

Eve Rosenhaft, Beating the Fascists? The German Communists and Political Violence 1929-1933 (Cambridge: Cambridge University Press, 1983), 58.

13 Pamela E. Swett, Neighbors and Enemies: The Culture of Radicalism in Berlin, 1929-1933 (Cambridge: Cambridge Universty Press, 2004).

14 Aristotle Kallis, 'Transnational fascism: The Fascist New Order, Violence, and Creative Destruction,' in Fascism Without Borders: Transnational Connections and Cooperations Between Movements and Regimes in Europe from 1918-1945, ed. Arnd Bauerkämper, Grzegorz Rossolinski-Liebe (New York: Berghahn Books, 2017), 41. 
a crucial 'key point of debate' during the interwar period. ${ }^{15}$ In the research about antifascist internal reflexivity and disputes about methods and eventual use of violence, Nigel Copsey has argued, at least when it comes to the British experience, for an 'anti-fascist minimum', ideologically rooted in the '(Enlightenment) conceptions of humanity and society' ${ }^{16}$ On the contrary, Tom Buchanan points out that the antifascist's propagandistic use of violence could have little to do with humanism or democratic ideals. Instead, 'it was often aimed at dehumanizing the fascists so that they could be physically attacked.17

Following this, it becomes important to understand antifascism, in the same way as its counterpart fascism; as a complex transnational political phenomenon. Especially during the 1930 s and 1940 s in Europe, antifascist activities or meetings took place in exile, or in order to escape repression and avoid revelation, in a 'borderless' clandestine world of transnational solidarity. At this time, antifascists also studied the various European versions of fascism and shared knowledge across borders about how to best combat and resist it. ${ }^{18}$ As Arnd Bauerkämper essentially points out: 'the transnational activities of fascists and antifascists were interrelated.' 19

15 Stéfanie Prezioso, 'Fighting Fascism With its Own Weapons: A Common Dark Side?' in Political Violence and Democracy in Western Europe, 1918-1940, ed. Chris Millington and Kevin Passmore (London: Palgrave Macmillan, 2015), 31. See also: Chris Millington, Fighting for France: Violence in Interwar French Politics (Oxford: Oxford University Press, 2018); Kristian Mennen, 'Necessary Evil, Last Resort or Totally Unacceptable? Social Democratic Discussions on Political Violence in Germany and the Netherlands,' in Political Violence and Democracy in Western Europe, 1918-1940, ed. Chris Millington and Kevin Passmore (London: Palgrave Macmillan, 2015).

16 Nigel Copsey, 'Preface: Towards a New Anti-Fascist "Minimum”?' in Varieties of Anti-Fascism: Britain and the Inter-War period, ed. Nigel Copsey and Andrzej Olechnowicz (Basingstoke: Palgrave MacMillan, 2010), xx.

17 Tom Buchanan, "Beyond Cable Street": New Approaches to the Historiography of Antifascism in Britain in the 1930s,' in Rethinking Antifascism: History, Memory and Politics, 1922 to the Present, ed. Hugo García, Mercedes Yusta, Xavier Tabet and Christina Climaco (New York, Oxford: Berghahn Books, 2016), 68.

18 Arnd Bauerkämper, 'Between Cooperation and Conflict: Perspectives of Historical Research on Transnational Fascism,' in Fascism Without Borders: Transnational Connections and Cooperations Between Movements and Regimes in Europe from 1918-1945, ed. Arnd Bauerkämper, Grzegorz Rossolinski-Liebe (New York: Berghahn Books, 2017), 36o-361.

19 Ibid., 361. 


\section{The Manifold Kick: Three Analytical Aspects}

Against this background, I will argue that the issue of the use of violence, from a diachronic and transnational historical perspective, can be considered as an ambivalent and contradictory core of transnational antifascism. This issue is always there, more or less, even for a peaceful and reformist liberal who always risks being forced to relate or respond to violence one way or another as a consequence of an antifascist engagement. In the following, I investigate three analytical aspects of this antifascist violence, in four historical contexts. The analysis starts in Sweden in 1934 and ends in Germany and the United States in 2017. It limits itself to a specific form of violence: the kick and the act of kicking. This 'antifascist kick', performed by members of antifascist groups on the political left-wing, is approached as a manifold sociocultural and discursive phenomenon and analysed with focus on different meanings, representations, and legitimation processes.

\section{The Kick as a Figurative Concept of Morality and Politics}

In the 1930s, hundreds of eager and militant Swedish antifascists on the political left-wing went to Spain, against Swedish legislation and official policy, and joined the International Brigades during the Spanish Civil War. Around 160 of them died. ${ }^{20}$ At this time, the Swedish antifascist milieu contained several various strategies, literal as well as figurative, about how to confront fascism and practice antifascism. One of those that stands out in an extraordinary way: to kick a fascist. This instructive antifascist kick evolved in various visual and narrative representations of antifascist left-wing propaganda produced and disseminated in Sweden during the 1930s. It called on various forms of kicking resistance based on morality and a political belief and related to an offensive image-language that also dehumanized the fascist. ${ }^{21}$ Even in textual representations, this antifascist kick played an important role as an exemplary, encouraging, and illustrative act.

One example of this is an episode that was referred to initially in the introduction to this article. In the spring 1934, when European fascism threw its shadows over Sweden, the membership paper of the Social Democratic Youth, named Frihet [Freedom], contained the short story 'Fire in the forest!' ('Skogen brinner?').

20 Michael Alpert, The Republican Army in the Spanish Civil War, 1936-1939 (Cambridge: Cambridge University Press, 2013); Michael Jackson, Fallen Sparrows: The International Brigades in the Spanish Civil War (Philadelphia: American Philosophical Society, 1994). 


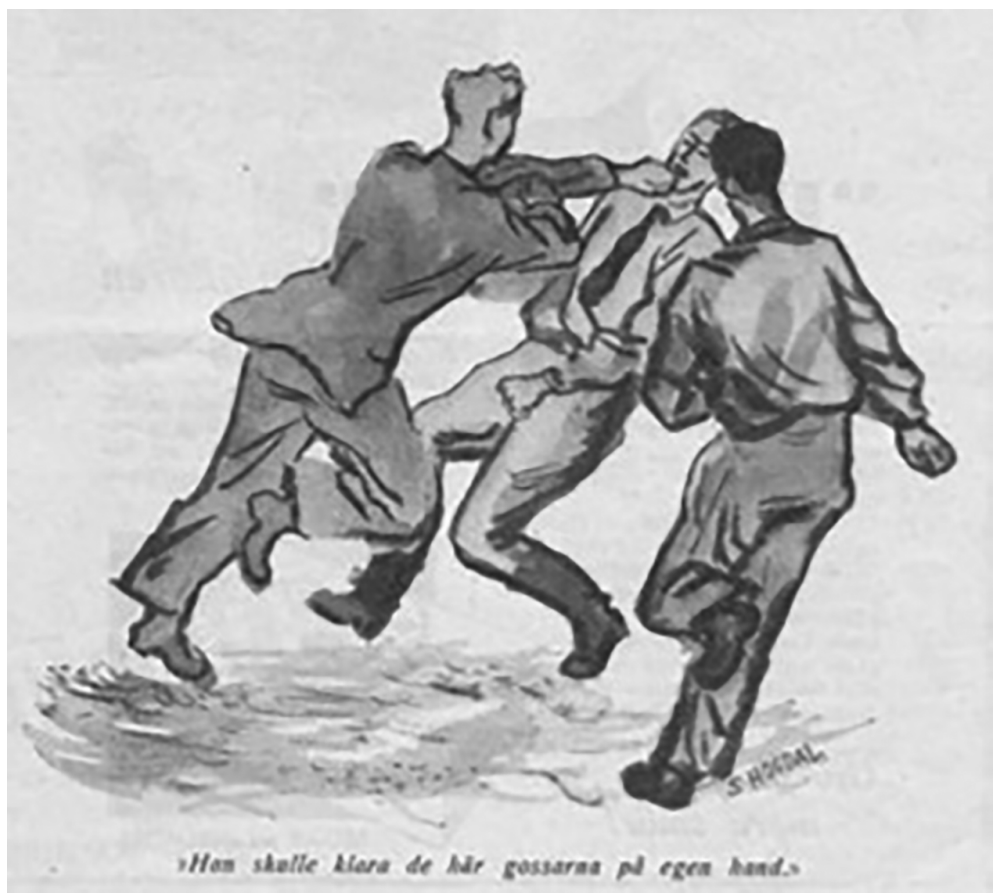

FIGURE 1 According to The Social Democratic Youth Organization in Sweden 1934, it could be necessary to figuratively confront Fascists with violence.

SOURCE: Frihet, 1 MAY 1934, 13. NATIONAL LIBRARY OF SWEDEN, STOCKHOLM.

In the two narratives published in mid-April and the first of May, the main character 'Sven' and his companion are violently attacked and wounded by several fascists ('Aryan Front Fighters') just outside their home turf, 'The Peoples Park'. But Sven strikes back in a cold-blooded, rational, and ruthless way. He frees his companion from the fascists' violence with a 'fierce punch and a well targeted kick.'22 In an exemplary and brave way, he defeats the fascists on his own and forces them into retreat.

The narrative about Sven and the burning forest is illustrative, and the moral message is clear: solidarity and class-consciousness are prioritized values in the resistance against fascism. As a young antifascist social democrat, you had to be true to these democratic ideals and defend them at all costs, even when the use of violence was necessary to safeguard freedom. But you had to do it in an honest and upright way, facing down your opponent in the eyes. Beating a fascist coward and seriously intimidated him was a very honourable action. ${ }^{23}$

22 Frihet, 15 April 1934, 11; Frihet, 1 January 1934, 13.

23 Frihet, 15 April 1934; Frihet, 1 January 1934. 
Even if Swedish antifascism during the 1930s was relatively peaceful in an international comparison, there could be various forms of antifascist violence. The Social Democratic Youth Organisation elaborated sophisticated strategies for how fascists should be attacked, assaulted, scared or humiliated. These included tactics that encouraged the use of symbolic and psychological violence. Another peaceful but nevertheless offensive antifascist tactic was humour in the form of songs, laughs and applauses in the wrong places. ${ }^{24}$ Adopting this tactic, Swedish young socialists followed a transnational antifascist trend. ${ }^{25}$

Another example of the 'antifascist kick', comes from the Swedish communist milieu in the same year, 1934. In a cartoon in their journal Idrottsfolket [The Sports People], the communist organization Arbetarnas Idrottsförbund [The Workers Sports Association], also gives instruction on how to treat a fascist. With the earth as a dark globe in the background, the picture shows a muscular and well-built football player who gives a soldier with a swastika-armlet and a bloody bayonet a very forceful kick in the backside. The explanatory image text beneath the cartoon says: 'With a penalty kick the proletarian athletes will cleanse the earth from fascists and warmongers.' ${ }^{26}$ To avoid misunderstandings, the message is clear: a class-conscious, active and athletic communist and football player kicks a fascist in their back in order to keep the world clean.

To sum up, in the Swedish 1930s, the antifascist kick seems to have functioned as a figurative concept that legitimized the use of violence for both young social democrats and athletic communists. This well-targeted penalty kick was motivated by a strong antifascist belief; an upright conviction, based on morality and political awareness, that fascists sometimes needed to be confronted with violence and then defeated and wiped out. For a real antifascist, thus, the masculine capacity to use violence if necessary was an admirable trait of character. ${ }^{27}$

24 Johan A. Lundin, 'Social Democratic Youth and Anti-Fascism in Sweden, 1929-1939,' in Anti-Fascism in the Nordic Countries: New Perspectives, Comparisons and Transnational Connections, ed. Kasper Braskén, Nigel Copsey and Johan A Lundin (London: Routledge, 2019), 111-123.

25 Fritz K. M. Hillenbrand, Underground Humor in Nazi Germany 1933-1945 (London: Routledge, 1995).

26 Idrottsfolket, no. 9, 1934, 3.

27 Liam Liburd, "Happy Warriors" on the Left: \#Milifandom, Politicised Masculinity and 1930s Anti-Fascism,' History Matters, 11 May 2015, http://www.historymatters.group.shef. ac.uk/happy-warriors-left-milifandom-politicised-masculinity-193os-anti-fascism/, accessed October 30, 2020. 


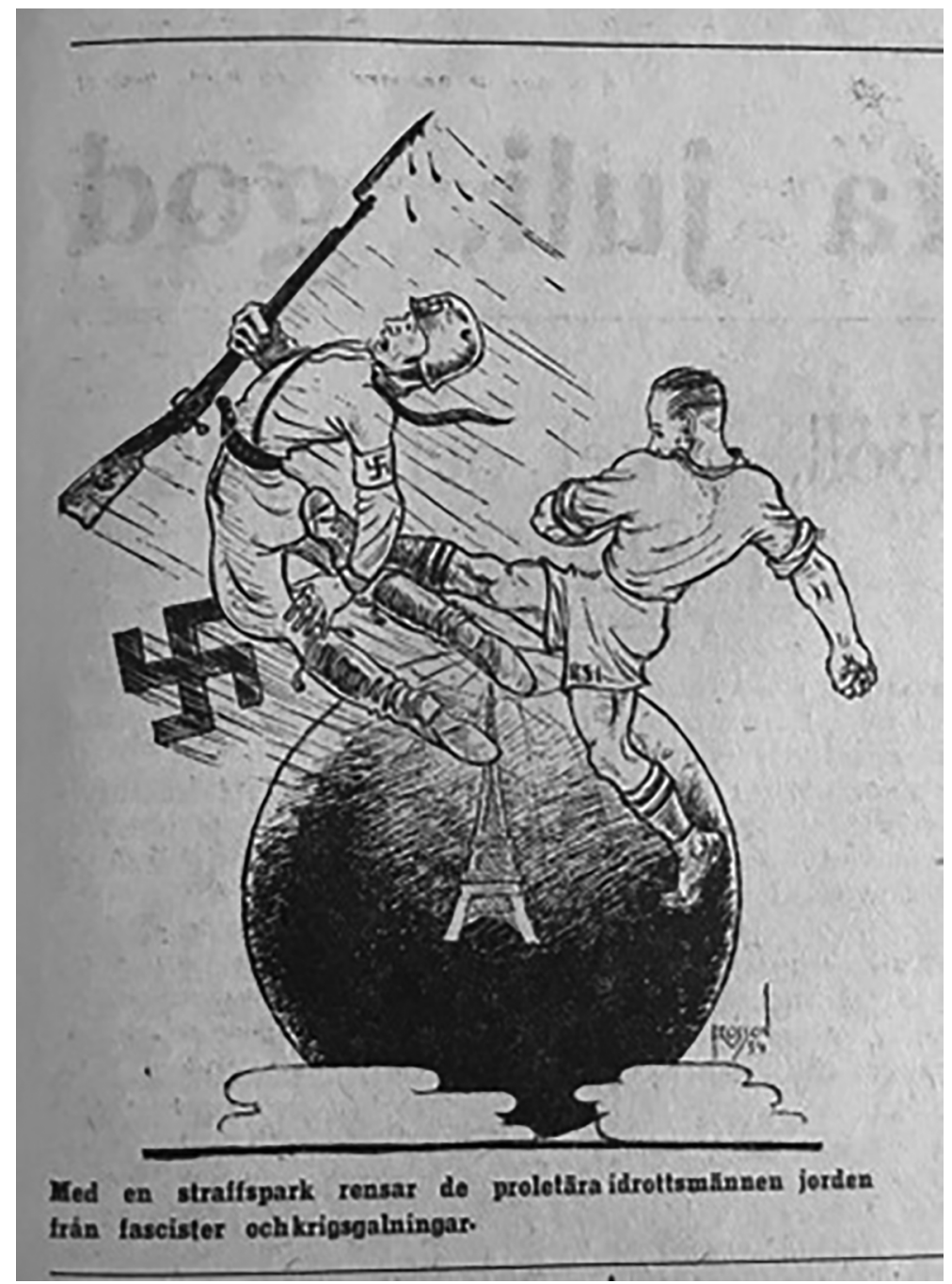

FIGURE 2 In 1934s' Sweden, The Communist's Sport Association encouraged their members to punish the fascists with a powerful penalty kick.

SOURCE: Idrottsfolket, NO. 9, 1934, 3. NATIONAL LIBRARY OF SWEDEN, STOCKHOLM.

\section{The Kick as a Symbolic Representation of the Antifascist Struggle}

In the transnational antifascist context, it is possible to follow this instructional antifascist kick into other forms. This also functions figuratively but in more symbolic and representational ways. During the 200os, the very emblematic symbolism associated with the expression 'Good Night White Pride' was common in antifascist contexts. Linked to the expression is a graphic image showing a standing figure kicking a laying defenceless silhouette in the head. 


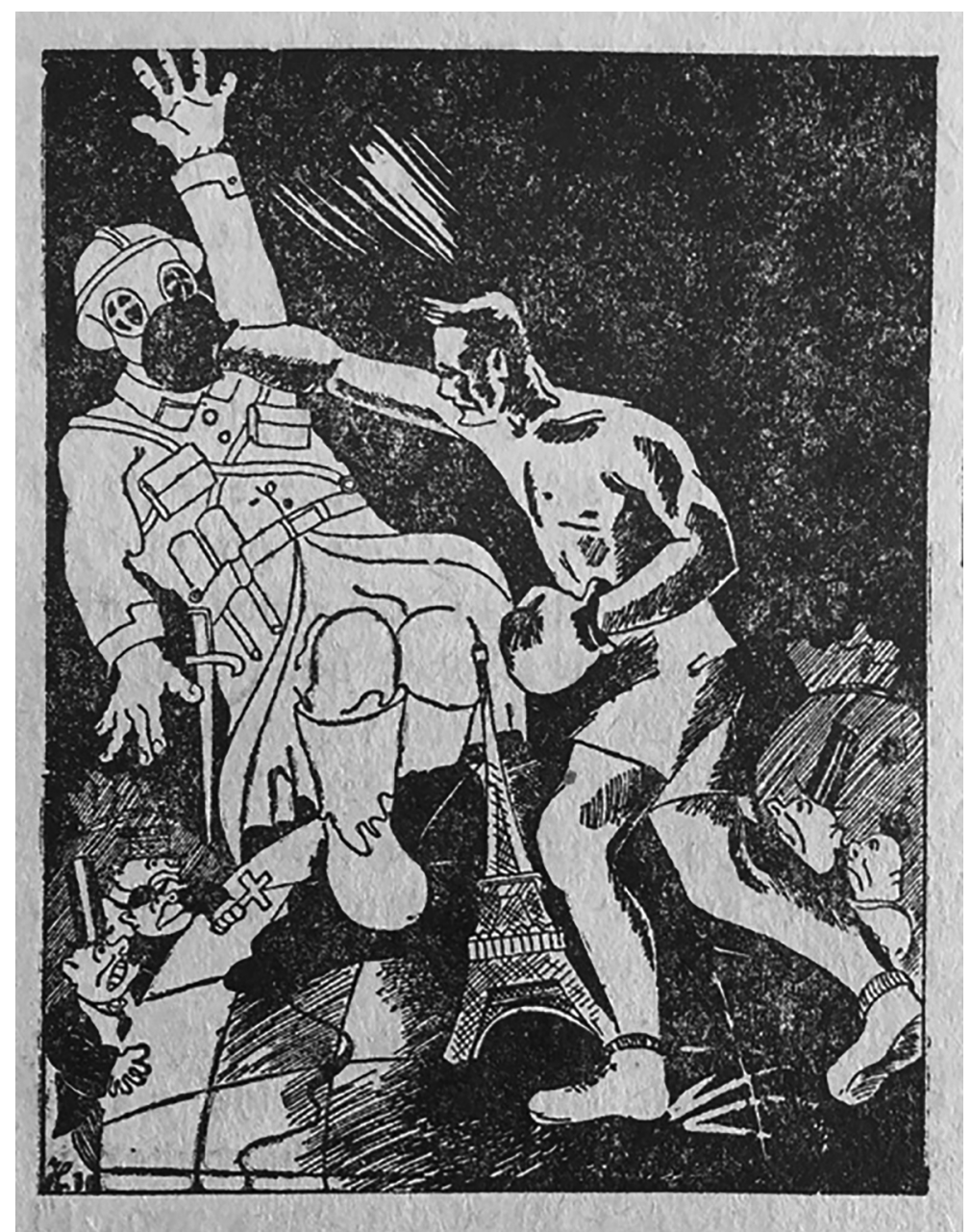

FIGURE 3 A communist boxer in Sweden 1934, in a successful round against fascism. SOURCE: Idrottsfolket, NO. 9, 1934, 5. NATIONAL LIBRARY OF SWEDEN, STOCKHOLM.

This text and image symbol could be found today on a broad sample of antifascist accessories, such as pins, t-shirts, caps, bags, flyers, banners, flags, stickers, etc., from the transnational ANTIFA context; the 'ANTIFA International. ${ }^{28}$

The story behind this symbolic success story goes back to 9 May 1998 and riots caused by a Ku Klux Klan rally in Ann Arbor, Michigan. A camera in the hands of Harlon Jones then caught the kick that soon became an iconographic antifascist image. The photo shows a black man in a blue cap, jeans and white

28 'Antifa International', https://antifainternational.tumblr.com, accessed 1 April 2019. 
t-shirt that violently kicks a white skinhead man in the head. The victim is defenceless and lying on the pavement, trying to rise, seemingly in vain. A passive spectator in the background watches the scene. On their homepage, ANTIFA proudly explains the photo as follows: 'This photo of Harlon Jones, an Ann Arbor anti-racist showing a racist scumbag some Michigan hospitality, is legendary and where the Good Night White Pride logo comes from.' ${ }^{29}$ Further on, they also say that this act in May 1998 was a lesson for the antifascist struggle in the future, a lesson telling that 'people standing together can take their streets back' and 'most importantly, fighting hate is not a crime!'30 The semantics of this standpoint seems forceful and principled: action, not passivity, is needed to resist the threat from the extreme right in the public sphere. ${ }^{31}$

In the aftermath of this event, this Good Night White Pride-symbolism has grown and has been disseminated transnationally within different antifascist milieus and organisations. In the influential German context, for example, this symbolism can be traced genealogically to the 'deutschen Hardcore-PunkSzene' of the 199os where a new struggle against 'Neonazis' emerged. ${ }^{32}$ For the German antifascists this symbolism advised that words are not enough when it comes to fight fascism, they had to be followed up with action: 'The Words must be followed by deeds. ${ }^{33}$ The use of violence seems a part of this agenda.

It is possible therefore to point to a quite remarkably symbolic development of the antifascist kick into a worldwide, iconographic, and truly transnational, image. This image appears to function figuratively, and it legitimizes and encourages the use of violence as something both honourable and necessary. Albeit the physical and original meaning of this deed, to violently kick a laying defenceless human being in the head, is hard to justify from an intellectual perspective, ANTIFA International has here made a violent and single event into a widespread, iconic, and important, symbol that effectively calls for

29 'The Story Behind the "Good Night White Pride" Image,' 'Antifa International', https:// antifainternational.tumblr.com/post/113107997559/the-story-behind-the-good-night-whitepride, accessed 1 April 2019 .

30 Ibid.

31 Cory Massimino and Thomas L. Knapp, ed., Fighting Fascism: Anti-fascism, Free Speech and Political Violence (The Center for Stateless Society, 2019).

32 Jamie Thomson, “No Fascist USA!" How Hardcore Punk Fuels the Antifa Movement,' The Guardian, 9 September 2017, https://www.theguardian.com/music/2017/sep/o9/ no-fascist-usa-how-hardcore-punk-fuels-the-antifa-movement, accessed October 3o, 2020; 'Hardcore - is more than music,' 'letsfightwhitepride.de', [March 2009], https://web. archive.org/web/20120918031859/http://letsfightwhitepride.de/index.php/aktuell.html, accessed 1 April 2019.

Ibid. 
physical resistance against white nationalists. As a cultural effect, it can also reduce them, the fascists, into dehumanized 'others.' ${ }^{34}$

\section{The Kick as an Exemplary Physical Behaviour of Antifascism}

A third and final version of the antifascist kick is probably the most obvious: the physical act of kicking as a social practice in itself. This violent part of a street fighting antifascist behaviour has been documented in riots and public disturbances since the interwar years. The two empirical examples I use here are both from the summer of 2017. The first comes from Germany where ANTIFA activists demonstrated every Monday that summer at a square in Dresden's city centre. At one of these events, on 27 July, some disturbances ensued after a female (note!) ANTIFA activist kicked and stomped some kind of pot plant, decorated with German flags, that nationalist counterdemonstrators ceremonially and peacefully had placed in front of the demonstrating ANTIFA group. The sequence is documented on YouTube, which of course must be watched with critical reservations for authenticity and provenance. Nevertheless, it becomes obvious that the kick is in focus here and completely changes the atmosphere at the square. The angry and resolute way in which the young antifascist sympathizer acts here, when she immediately runs ahead and destroys the symbolic gift, is undoubtedly a conscious and considered act. She smashes the gift and demonstratively humiliates those who gave it.

The second example comes from the U.S. and the violent disturbances that broke out in a park in Berkeley, California, on 27 August 2017, when ANTIFA activists confronted a right-wing demonstration. The day after, The Washington Post reported extensively on the incidents. ${ }^{35}$ Notwithstanding the usual caveats regarding journalistic style, it is nevertheless telling how the paper describes the actions of the ANTIFA activists:

Shortly after, violence began to flare. A pepper-spray-wielding Trump supporter was smacked to the ground with homemade shields. Another was attacked by five black-clad antifa members, each windmilling kicks and punches into a man desperately trying to protect himself. A

34 Buchanan, 'Beyond Cable Street,' 68; Ariel Kock, 'Trends in Anti-Fascist and Anarchist Recruitment and Mobilization,' Journal for Deradicalization, no. 14 (2018): 1-51, available at http://journals.sfu.ca/jd/index.php/jd/article/view/134, accessed October 31, 2020.

'Black-clad antifa members attack peaceful right-wing demonstrators in Berkeley,' 'washingtonpost.com', August 28, 2017, https://www.washingtonpost.com/news/morning$\mathrm{mix} / \mathrm{wp} / 2017 / 08 / 28 /$ black-clad-antifa-attack-right-wing-demonstrators-in-berkeley, accessed 29 March 2019. 
conservative group leader retreated for safety behind a line of riot police as marchers chucked water bottles, shot of pepper spray and screamed, 'Fascists go home!'36

In these sequences, which also are available on YouTube, violence quickly escalates. There it is possible to witness the 'windmilling kicks', practised by some of the ANTIFA activists. To clarify: a 'windmill kick' is a special type of karate-kick where the athlete kicks his counterpart in the same move as he is doing a standing somersault. In this context it also carries a political meaning of an effective way to fight fascists. In other words: this acrobatic and athletic act of the 'windmill kick', is here transformed to an 'antifascist kick'.

When concluding this third example, it becomes quite obvious that this literal antifascist kick, the physical act of kicking a fascist, appears in contexts characterized by group dynamics and strong internal aggression and excitement. The events in both Dresden and Berkeley reveals how 'the antifascist kick' as a part of an antifascist behaviour is socio-culturally embedded in a very meaningful and important political public space: the square. In modern liberal democracies, this place functions as an antagonistic 'free-zone' for challenging political opponents or the norms and boundaries around how to make politics. Thus, the use of violence could appear as something reasonable.

Here it also seems obvious that the act of kicking is an act of contempt and disgust: persons labelled as 'fascists' are seen as weak cowards, and persons that you barely not need to consider as human beings. The logic of dehumanizing a fascist is here maintained by 'the antifascist kick'. Accordingly, fascism is treated as an irrational political disease, overall something that, in the name of antifascism, should be 'kicked out', once and for all.

\section{Conclusion: The Kick as an Antifascist Signifier}

From its origins in the interwar years, antifascism has comprised a vivid transnational sociocultural practice. Within this history, 'the antifascist kick' has been a common thread within the multifaceted field of antifascism and its various conceptual worlds. The three analytical aspects in this article demonstrate how antifascist culture conceptualized this kick: as a figurative model for antifascist morality, upright political conviction, and a masculine capacity to use violence if necessary. The 'antifascist kick' is a symbolic representation of

36 Ibid. 
antifascist struggle that legitimizes and normalises the use of violence against 'the other'; an exemplary physical act in confrontations with fascists on the streets or in the squares.

Here, I conclude that the origins of this signifying antifascist kick lie in the formative antifascist era during the interwar years in Europe, as an approved part of a transnational antifascist sociocultural practice. This act is conceptualized in various ways within the antifascist field and is used by different groups to legitimize their enemy-images and use of violence under the recurring phrase 'antifascism is self-defence'. Through this, it has also become possible for some of these groups to excuse a rowdy, irresponsible, and irrational political behaviour with a romantic and anarchistic disguise, since their political agendas actually do not have much to do with antifascism at all. In this, the historical core of resistance against fascism is sometimes marginalized, and various aggressive and subversive conceptions, which are against, for example, the state, the authorities, the police, the capitalist economy etc., are taking over the scene - and the label. ${ }^{37}$

With these three forms - a figurative concept of morality and politics, a symbolic representation of the antifascist struggle, and an exemplary physical behaviour of antifascism - the antifascist kick also reproduces strong spiritual and uplifting semantics. Thus, the use of violence, for a boxer, a karate-athlete, and a wrestler, as well as for an 'antifascist' street activist or a football hooligan, is also a matter of getting a kick in the sense of drawing stimulation from a group dynamic force, often in an adolescent context. ${ }^{38}$ Hypothetically, I therefore propose that the antifascist need for violence against fascists, arouses and strengthens a fighting spirit within some 'antifascist' groups. This ties these groups together with hegemonic masculine norms and habits and could make them noticeably more narrow-minded - and violent. ${ }^{39}$ In the transnational antifascist community, such a subcultural kick - a strong, internal, and emotional form of political conceptualization - bonds antifascist groups together against various enemies, not barely actual fascists. ${ }^{40}$

37 Kock, 'Trends in Anti-Fascist and Anarchist Recruitment.'

38 The Undertones, 'Teenage Kicks,' [song] (1978), available at https://youtu.be/wAtUw6lxcis, accessed 1 April 2019 .

39 See for example Andrew Hodges, 'Violence, and Masculinity Amongst Left-Wing Ultras in Post-Yugoslav Space,' Sport in Society: Cultures, Commerce, Media, Politics 19, no. 2 (2016): 174-186, http://dx.doi.org/10.108o/17430437.2015.1067771.

40 Simon Clarke, Paul Hoggett, Simon Thompson, ed., Emotion, Politics and Society (Basingstoke: Palgrave MacMillan, 2006). 
On this point, it becomes possible to use Robert D. Putnam's classic analytical notions of 'bonding social capital' and 'bridging social capital' to more deeply understand the strength in transnational antifascism, and what seems like its diachronic and transnational habit to kick. The antifascist kick may actually have the ability to both stimulate internal values, ideology and habits within a sociocultural group and build relations and establish connections externally, between sociocultural groups sharing interests, memories and experiences. ${ }^{41}$ Another, more controversial, way to theoretically understand the strength of this antifascist kick, is to use Robert O. Paxton's very pertinent definition of fascism as 'a form of political behaviour'. 42 If antifascism is considered antithetically related to fascism, and not only seen as a question of ideology, this theoretical parallel may make sense. The act of kicking as an actual political behaviour carries a variety of significant meanings within transnational antifascism and its malleable and fluid culture.

The antifascist kick is obviously historically ambiguous. It appears paradoxically, both as a defensive democratic bulwark with a strong and reasonable backbone and as an offensive and aggressive group dynamic force, implying the use of violence against everyone considered 'fascist'. It transcends national borders as well as chronological eras and reproduces both literal and figurative conceptions within transnational antifascism and its cultural dynamics from its early stages during the interwar period. And in the name of antifascism, it carries the capacity to challenge the boundaries between democracy and anarchy. On this point, the limited analyses in this article should serve as an important reminder of the fundamentally crucial distinction between a form of antifascism that uses violence to defend and protect a free, peaceful, and democratic society, and other forms that use violence more in an unsophisticated masculinized manner, or as an intrinsic value in a romantic and idyllic imagination of 'antifascism'.

\footnotetext{
41 Robert D. Putnam, Bowling Alone: The Collapse and Revival of American Community (New York: Simon \& Schuster, 2000).

42 Robert O. Paxton, The Anatomy of Fascism (London: Penguin Books, 2005), 218.
} 